$\begin{aligned} & \text { Anny Wynchank } \text { Perception of the relationship } \\ & \text { Prof Anny Wynchank is research } \text { France-Africa by André Gide and } \\ & \text { associate at the School of Languages } \\ & \text { and Literatures of the University of } \\ & \text { Cape Town, South Africa. }\end{aligned}$

Perception of the relationship FranceAfrica by André Gide and Camara Laye

André Gide, the French traveller, went to Congo and Chad in 1925, on an official mission. He noted his impressions in his journal, published later under two titles: Voyage au Congo (Voyage to the Congo) and Retour du Tchad (Return from Chad). He expressed delight at the flora and fauna but presented the Africans as primitive beings, without spiritual or cultural values. His travels turned into a humanitarian quest when he witnessed the treatment inflicted on the natives by employees of the monopolistic rubber companies. The dilettrante and aesthete Gide became a man commintted to a struggle to improve the life of Africans in these regions. The publication of his books, and of articles describing the situations, had important positive consequences. Thirty years after Gide, a Guinean writer, Camara Laye dismantled the dichés attached to these supposedly "primitive barbarians". He offers another picture of the Africans and of Africa in his novel, le Regard du Roi (The Radiance of the King, 1954). The hero is a troubled Frenchman travelling in Africa. Camara inverted the roles traditionally attributed to Europe and Africa. The crossing of various regions is presented as initiatory tests which bring about the hero's palingenesis. Camara shows that a spiritual Africa brought peace and salvation to the Frenchman. The article will contrast these perceptions. Key words: André Gide, Voyage au Congo (Voyage to the Congo), Retour du Tchad (Return from Chad), Camara Laye, le Regard du Roi (The Radiance of the King), initiatory voyage.

\title{
Introduction
}

After the European expeditions in Africa at the end of the XIXth century, such as the military ventures of Marchand and Voulet-Chanoine and civilian exploratory missions, like those of René Caillé and Savorgnan de Brazza, ethnographers and travellers went to Africa, either for scientific reasons or attracted by the unknown and the exotic. Many of them kept journals, noting what they found picturesque and strange and recording their experiences. They typically presented the African as a primitive being, without spiritual or cultural values. In 1925, André Gide, together with his companion, Marc Allégret, went to the Congo and Chad, on an official mission of the Minister of Colonies, Léon Perrier. This official backing provided the enterprise with all the material and human resources it would need to succeed. Gide described in great detail the regions he crossed, noting his impressions in his journal, which was published on his return, in two volumes: Voyage au Congo (Voyage to the Congo) and le Retour $d u$ Tchad (Return from Chad). His perception of the Africans differed little from that of his predecessors. 
Thirty years after the publication of Gide's books, a Guinean writer Camara Laye, who was well aware of the typical European views of Africans, dismantled European clichés attached to these supposedly primitive barbarians. He offered a different picture of the Africans and of Africa in his novel, le Regard du Roi (1954), published as The Radiance of the King.

I propose to compare two visions of Africa and the Africans, that of the French traveller André Gide - and I have concentrated my analysis on Voyage au Congo - and that of the African, Camara Laye, as it is expressed in his novel. Its hero, Clarence, is a troubled Frenchman travelling in Africa. I shall see how Camara inverts the roles traditionally attributed to Europe and Africa.

\section{André Gide's Africa}

Gide's journal is marked by the pleasure of his experience of exoticism, delight at wild nature and a strong taste for natural history. Gide wishes his reader to understand what he saw, or what he believes he saw. He depicts villages, birds, the flora and fauna and expresses his overwhelming wonder at the waterfalls, flowers, ferns, sunsets and tornados. He admires the virgin forest, its trees, its vegetation, the "great mirror of the Congo," with its islets "so harmoniously disposed that you feel you are circulating within a water park" (Journal, 701). ${ }^{1}$ The perfume of some arborescent shrubs in Bouar is potent. "Neither jasmine nor lily of the valley, nor lilac, nor rose has the strong, exquisite scent of this bush" (Journal, 794). ${ }^{2}$

Gide is enchanted by the extraordinary butterflies, which he collects to bring back to France. The term "admirable" recurs ceaselessly in his narrative. From his footnotes (i.e. references to previously published newspapers, others' accounts of their travels, etc.), we learn that Gide was well prepared for this adventure. He often compares his impressions to those of travellers who preceded him. Thus, one footnote informs us that Auguste Chevalier, proceeding up the River Congo in August 1902, described this region as full of flowers (Journal, 701). On the contrary, Gide finds "no flowers; not a single note of colour other than green" (Journal, 701). ${ }^{3}$ He notes that the flower season is finished. It is very short lived here. Gide also mentions the Citroën expedition (Journal, 729), and the supposedly "ethnographic" films, made by its members, which were in reality, he states, the result of well organised staging.

We may wonder whether Gide's preparatory reading might have been a filter between his perceptions and reality. Often, the landscapes he describes in his journal, as well as the people, are those which concord with his prior representation of them. "This morning, the Logone harmonises fairly exactly with the image of it which I had in my mind" he writes (Journal, 874). ${ }^{4}$ On the banks of the Congo, "the spectacle gets closer to what I thought it would be; there is a good likeness" he notes (Journal, 702). ${ }^{5} \mathrm{He}$ is more or less satisfied according to whether the spectacle he experiences 
matches his imaginings or not. He evokes an "enchanted Brocéliande" (Journal, 703). ${ }^{6}$ But he does not go as far as peopling it with King Arthur and his knights. When the landscape does not meet his expectations, he feels wronged. "This forest disappoints me. I hope to find something better elsewhere. This one is not very tall; I was expecting more shadow, more mystery and strangeness. There are neither flowers nor arborescent ferns here and when I request them, like an item on the programme skipped by the organisers, I am told that 'it is not in this region'" (Journal, 705). ${ }^{7}$

Gide discovers in this African Eden the sensuous nature that recurs in his phantasms: "deep bays of greenery", where one can find "mysterious alcoves" between the trees, and "when the lianas hug them, it is with such soft curves, that their embrace seems voluptuous, more like loving intimacy than suffocation" (Journal, 702-03). ${ }^{8}$ The phantasm is so powerful that, one day, it might annul the memory of the real thing, when reality does not present itself the way the traveller had at first imagined it. "My imaginary representation of this country was so vivid (I mean I was imagining it so strongly) that I wonder if later, this false image will replace the actual experience" (Journal, 733). ${ }^{9}$

As for the Africans, contrary to what he declares - when he is asked: "What are you going to seek there [in the Congo]", he answers: "I shall find out when I get there!" (Journal, 683) ${ }^{10}$ - Gide does not go to Africa with an open mind. His expectations have already been formed and indeed he will later write for the German periodical Die Koralle, that, in the Congo, he was going to look for "the savage, the primitive, a naked humanity without history; a nature free of any enslavement" (in Durosay 1991: 21). ${ }^{11}$ Gide depicts the Africans as simple and innocent people, not stupid, but with a "primitive" mentality. For him this population, "without any civilisation" is interesting because it represents humanity at the dawn of time. Gide will find in the theories of Lévy-Bruhl the confirmation of these convictions. Later, he will add a note to his Journal quoting the work of this philosopher, Primitive mentality, to explain a statement which had surprised him during his voyage. In Yakoua, the peasants had claimed that the crocodiles of the lake never attacked humans. Lévy-Bruhl's theories clarify this statement and Gide understands that "for the native, the accidental does not exist. The notion of the fortuitous cannot reach him. The crocodile is 'naturally harmless' and if it happens to gobble up a man, it is because a sorcerer has delivered him to it" (Journal, 835). ${ }^{12}$

Gide's observations, and the analysis of these "primitive" people, will allow him, a civilised man, to know himself better. Indeed, he declares in a talk given in Brussels, "more or less deeply buried under the sediments patiently deposited by Culture, is to be found the savage 'self' which it is fascinating to discover in its native state" (Gide 1988: 35). ${ }^{13}$ Therefore it is not the African who interests Gide directly, but the European. In the midst of the "African savagery" (Gide 1988: 34), ${ }^{14}$ he will learn to know and understand better European civilisation. 
At no time does he concede to the Africans a system of metaphysical thinking, and spiritual and cultural values. He only grants them an obscure and imperfect intelligence and condescendingly places them mid way between the animal and a civilised being. "I do not wish to make the Black man more intelligent than he is. But his supposed dumbness can only be similar to that of the animal - natural" he declares (Journal, 752). ${ }^{15}$ He calls a village chief "stupid" because he cannot satisfactorily answer the question: "Why was the cassava not harvested in good time?" (Journal, 752). "In general, the concept 'why' is not understood by the natives; and I even doubt whether some equivalent word exists in most of their languages. [...] It seems that this people's brains are incapable of establishing a link between cause and effect" (Journal, 752). ${ }^{16} \mathrm{He}$ makes a judgement which is as perfunctory as peremptory: "I think they are only capable of very little development; their brains are numb and stagnant, more often than not as if in a dense night" (Journal, 765). ${ }^{17}$ This outrageous and racist remark reveals Gide's incapacity to recognise his own most irrational convictions, because he has a total faith in the absolute superiority of his own culture. A priori, for Gide, Black Africa is a savage continent, without any spirituality. This is exactly what Camara Laye will want to refute in his novel. On the other hand, Gide finds that the further north in Africa one goes - therefore the closer one gets to the Maghreb - the more spiritual the populations become. "It seems that they [the natives] become more refined and spiritual as you go northwards" he claims while in Yakoua (Journal, 836). ${ }^{18}$ Previously, in Algeria and Tunisia, he had mixed with the inhabitants, mingled willingly with the crowd in the souks, and entered the fondouks ${ }^{19}$ fearlessly. In the Congo, he keeps a prudent distance from the masses, unwilling to enter villagers' huts. He has little communication with the natives, even through his interpreters.

While travelling, Gide never forgets his European civilisation. He carries with him his prejudices, his fancies and his phantasms, together with his butterfly nets and his favourite classics - his Bossuet, La Fontaine, Milton, Browning and Corneille. An unkind gossip said that Gide "went as far as Chad with the only apparent purpose of chasing butterflies, studying the Second Faust, slating Britannicus and comparing wart hogs to Henri Béraud" (Dambrus 1983: 239). ${ }^{20}$ The prejudices of a delicate Westerner sometimes surface when confronted with some spectacles which he finds painful. Thus, he cannot help expressing his repulsion when observing the contortions of old women dancing. "This preposterous wriggling of aged ladies is rather dreadful", he complains (Journal, 748). ${ }^{21}$ Further on he writes, "the shameless gigging about of decrepit matrons is extremely painful" (Journal, 752). ${ }^{22}$

On the other hand, the faces and silhouettes he notices in Equatorial Africa are those which correspond to his phantasms, which have always attracted and enchanted him in Algeria and Tunisia. In Conakry, beautiful children "bare chested, cheerful, with languid eyes" (Journal, 685) ${ }^{23}$ delight him. His subjectivity here is evident: the chimera reappears, the myth of an idyllic happiness, in a virgin, untouched nature, 
for "everything here seems to promise happiness, voluptuous delight and oblivion" (Journal, 685). ${ }^{24}$ Africa gives a concrete shape to his phantasm of perfect harmony between man and nature. "How admirably these black skins mix and harmonise in the great vegetal symphony, to the point where bodies can hardly be distinguished from the tree trunks and seem to have metamorphosed their limbs into branches and lianas, as in mythology" (Journal, 874). ${ }^{25}$ The constant aspect of the Gidian itinerary mentioned by Daniel Durosay (1988: 26) can be detected here. Edward Said asserted that the Orient was a creation of the West. Is Gidian Africa a creation of the writer?

\section{André Gide, the humanitarian}

Gide's adventure in the Congo was intended to be a face to face interaction with primitive people. However, after a few weeks, it changed into a humanitarian investigation. First, he notes the attitude of some French who reside in the Congo, which he deplores. Some shopkeepers "came to the country determined to make a fortune rapidly. And to the detriment of the natives and of the country, they succeed," Gide writes (Journal, 719). ${ }^{26}$ Later, the traveller is horrified by the terrible treatment and the injustice inflicted on the natives by the concessionary companies which have a monopoly for the collection of rubber and which exploit the natives. The exploitation of rubber is accomplished using incredibly savage methods. What the companies call "compulsory service" is for Gide an euphemism for a new slavery; the natives are forced to collect rubber. He listens to the complaints of the villagers and his observations dictate his conduct. He now knows what his mission is: he must intervene and approach the French authorities to help this exploited people and redress their unjust treatment.

Thus, in the course of his voyage, Gide is sickened by the way in which a team of women is treated by the militiamen who control them, while they work repairing the road along which Gide and his escort are travelling. This road, damaged by a recent storm, is used exclusively by the car which takes the representatives of the Forestière, the concessionary company, accompanied by the Administrator, to the market once a month (Journal,739). "This poor human cattle was drenched in a downpour. A number of them were breastfeeding while working" (Journal, 739). ${ }^{27}$ Some of them may even be buried at the bottom of the holes they are digging without the appropriate tools, to extract the sandy soil for the backfill. Progressively, Gide becomes aware of the reality of the hell in which these natives are living - cruel repression, the carelessness of some Administrators and shameful exaction by the concessionary companies. "When I accepted the mission with which I was entrusted, I did not quite know at first, to what I was committing myself, what could be my role and in which way I could be useful. Now, I know and I am beginning to believe that I will not have come in vain" (Journal, 744). ${ }^{28}$ He must draw the attention of the French government to the odious behaviour of the concessionary companies in order to put a stop to it. 
It must be noticed that at no moment does Gide call into question the principle of colonialism. He evokes France's civilising mission and admires the sense of responsibility and the dedication of some Administrators, Mr de Coppet for instance. In some regions, he notices the wellbeing brought by the French to the Africans; cleanliness, order, hygiene, education, and some general comfort. Thus, France has created schools to educate the sons of chiefs and of native dignitaries. The three oldest sons of the Sultan of Rafaï have received a French education in such a school in Gorée, in preparation for their future responsibilities. In a letter to Dorothy Bussy, dated 21 October 1925 and sent from Bangui, Gide extols the benefits of colonisation. Thanks to the "very remarkable Governor of Oubangui-Chari, Mr Lamblin," the country "is coming out of its long misery. Cultivated fields are everywhere, clean huts, villages inhabited by well fed, healthy and prolific people, naked and happy" (Cahiers André Gide 1981: 50). ${ }^{29}$

Concerning the social injustices of the concessionary companies, on his return to France, Gide will not be at peace with himself until he has addressed this situation. He will try to put a stop to this system, first with the publication of his books, then by publishing in la Revue de Paris (the Paris Review) of 15 October 1927, an article on the distress of the inhabitants of Equatorial Africa: France has taken on responsibilities towards the Africans which it has no right to shirk. "It is high time to act [...], to put an end to a system which is not only stupid and disgracefully costly but inhumane and dishonouring for France" (Journal, 1040). ${ }^{30}$ It is important to point out he felt this cruel system was dishonouring for France.

Voyage au Congo and le Retour du Tchad produced concrete results: they caused a brouhaha that brought attention to the behaviour of concessionary companies. After Gide's two books and their appendices were published, Léon Blum launched a campaign against the concessions and Léon Perrier promised that none of those that were to come to end in 1929 would be renewed or extended under the same conditions (Chadourne 1968).

\section{Camara Laye's French traveller}

In 1954 a Guinean, Camara Laye, published his novel le Regard du Roi, translated and published as The Radiance of the King. ${ }^{31}$ In it, he wishes to overturn the then current stereotypes of Europeans and Africans. Was Camara Laye acquainted with Voyage au Congo and le Retour du Tchad? This could be possible, as Camara had spent some years in France.

Some faint echos of Gide's account can be noted in his novel. It is natural to find in the African novelist's text the kind of criticism of French colonisers that had been expressed by Gide in his Voyage au Congo. In the same way as Gide had deplored the attitudes of small white businessmen who worked in the Congo, as mentioned earlier, Camara showed that those whites who lived in the town of Adramé were work- 
shy and totally idle persons (Radiance, 9). They spent most of their time playing cards and consuming iced, alcoholic drinks. Clarence noted that "all the white men who came to that hotel were gamblers and they had more money that they knew what to do with..." (Radiance, 9). Also, Clarence, like Gide, wishes to meet the king of the region where he finds himself. But whereas Gide was feted enthusiastically when he arrived on the esplanade of Rafaï, in Oubangui-Chari, where the Sultan was holding court (Journal, 727), Clarence was crushed and knocked hither and thither by movements of the crowd on the esplanade of Adramé, when he came to see the king. Finally, and more significantly, another curious and telling echo of Gide's travels occurs later. Attracted by the crowd on the esplanade of Adramé, Clarence glimpses the nation's king, an enigmatic adolescent with an inscrutable smile, simultaneously both vigorous and delicate. Clarence's first impression of the king may be an allusion to the relationship between Gide and Marc Allégret. Camara indicates that Clarence has ambiguous feelings towards the king, as expressed when he writes:

He [Clarence] began to think about love ... Yes, it seemed that it might be possible to love this frail adolescent, yes, it would be possible, despite the pitch-black night of his skin ... But why 'despite the pitch-black night of his skin'? ... What has the color of a person's skin got to do with love? ... Perhaps the midnight of those limbs would help to lift love to its purest peak; yes it kept love at an ideal remove, it prevented it from being changed into one knows not what, or only too well ... into a hurtful bestiality ... (Radiance, 19).

The love referred to here was perhaps a gay relationship. Let us not forget that while he was travelling in Africa, Gide was accompanied by the youthful Marc Allégret, with whom he had established a physical relationship some years before. Is there an allusion here to that relationship? But the indefinable feeling that was aroused in Clarence by the young king was spiritualised by his skin colour. "The midnight of those limbs" clearly transforms and elevates Clarence's love (Radiance, 19). Now he realises his quest is to meet the king, who, as the beggar he meets informs him, would be found in the South. The beggar offers to lead him there. Thus Clarence decides to go southwards to wait for the king. Now he has found a purpose for his life and can achieve his own salvation.

It is not crucial to know whether Camara had read Voyage au Congo, or not. Ethnological reports were well known. The hero of his novel, Clarence, was a white, middle class Frenchman, who had come to Africa seeking new horizons and doubtlessly hoping to make his fortune. Apparently crossing regions similar to those that Gide had visited, Clarence was the exact antithesis of actual French travellers of that time.

Clarence is clearly not the civilised and superior white man that he believes himself to be. "I am not just anybody," he proudly informs the beggar. "I am a white man!" (Radiance, 8). The beggar "made as if to spit", and scornfully responded "a white 
man!" (Radiance, 8). Thus, humiliated and undermined, Clarence was far from being feared or respected by Africans. Camara presents him as a dull white, in a continuous stupor. "For the greater part of the time, he is only half-awake, he is walking along in a half-sleep. [...] He is overwhelmed by an irresistible languor" (Radiance, 94). This seems to be a rebuttal of Gide's claim that Africans "have a stagnant, stupid brain that seems most of the time in the midst of a dense night" (Journal, 765).

Just like Gide at times, the traveller Clarence is disillusioned by what he discovers in Africa. While in France he had imagined the South to be a form of tropical paradise, "a hammock hanging between a pair of coconut palms, at the edge of a lagoon!", a vanilla scented tropical breeze wafting by, "the foliage greener than anywhere else, and the flowers more brilliant - flowers like birds, and plants like fountains, and a sea that was of a profounder blue" (Radiance, 102-03). But what does he find? "The foliage is not greener; it's even rather gray, rather ashen. And the sky? ... But you can hardly see the sky!" (Radiance, 103). As to the azure limpidity of the water? ... "There is the stagnant water of ponds and the muddy water of the rivers. If you drink it, it's like a mouthful of mud that ..." (Radiance, 103).

Camara never specifies which region of Africa Clarence is crossing. The landscapes that Gide had described in such great detail are here stereotyped. They are those which a European imagines when he thinks of Africa: the virgin forest, with dense undergrowth, almost suffocated by creepers, flowers and other plants, mud hut villages and towns surrounded by crenellated walls, enclosing, labyrinth-like narrow streets. Camara does not describe these settings to create exoticism. He gives them a symbolic role. He presents them as the stages of a personal and private voyage that leads Clarence through the different steps of an initiation to a final renaissance.

\section{Clarence's trials and tribulations}

Towns are places for humiliation and shame. In Adramé, led on by his fellow Frenchmen, Clarence falls prey to an artificial paradise of gaming and drinking. It is there that he experiences poverty and total moral degeneration. In Aziana, while waiting for the king, and without realising it, Clarence becomes a stud in the harem of the village chief. This situation had been contrived after an arrangement between the beggar and the chieftain, to whom Clarence had virtually been sold. Night after night, there was a succession of harem women who came into his bed, while he remained dazed and almost unconscious, a consequence of narcotic vapours which emanated from those flowers and plants with which they had carefully chosen to fill his hut. He had no memory of these nights, but only a sense of complete fatigue, heaviness, drowsiness and moral blemish. "His head felt horribly heavy and his body odiously sticky, his whole body - nose, mouth, eyes - the eyes particularly - and also inside his body, his lungs, belly, and everything the odor found no difficulty in 
reaching as well as everything it could reach only by devious means - his heart, muscles, veins, the very blood in is veins - all this was heavy and sticky, glutinous and turgid, and as if made of lead (Radiance, 191). So because of Clarence, the harem acquires a mixed blood population. Camara here ironically reverses the typical European fantasy of male Africans' sexual prowess. Clarence, who had been dreaming of a state of saintly purity that would result from his meeting the king, is now thrust into the most "hurtful bestiality" in Aziana (Radiance, 19).

The Frenchman does not understand the customs and rites of this culture in which he is now immersed. He finds them absurd. In Adramé, it seems deviant and senseless that only the most loyal and devoted of the king's subjects are considered suitable to become human sacrifices. It is because only they "are worthy of the altars," the beggar explains (Radiance, 29). Clarence cannot conceive that such a sacrifice brings about their redemption. He is unable to bear their ghastly cries, "screams that were not allowed to finish. A knife stuck in the throat gave them no chance to elaborate their sufferings" and he attempts to intervene (Radiance, 31).

Clarence feels that life is absurd and this is symbolised in the novel by the frequent hounding and chases in restricted and winding spaces. He has an impression of running in circles fruitlessly, never finding a way out of the murky alleys of Adramé and unable to leave the labyrinth around the High Court. These alleyways are like an underground maze in Aziana, seeming as dark as cellars or the depths of a tropical forest. Why "these endless comings and goings", "the same tunnel, the same vertigo that comes from turning round and round all the time"? he asks the beggar when in the forest" (Radiance, 94). "Wherever we go it is the same path and the same tunnel ..." (Radiance, 94).

As Clarence trudges towards the south, or while he is waiting indefinitely for the arrival of the king in Aziana, the absurdity of his condition and of the world in which he finds himself, forcibly strike him. He is aware of the emptiness of his meaningless life, which continues unchanging day after day. Clarence accuses the beggar of walking, solely for the sake of walking and asks him: "What sense is there in walking in circles in the forest". "I do what everyone else does," replies the beggar (Radiance, 108). In one way or another it is necessary to fill this absurd life, where nothing is meaningful (Radiance, 261). Clarence tries to "kill" time, while waiting for the king. "'Another killing day', he thought (Radiance, 147). "Ah, yes, he had killed a good deal of time already. [...] All those days, when one came to think of it, were just a great emptiness" (Radiance, 147).

\section{Camara Laye's Africa}

It is likely that Camara Laye had intended Clarence's travel and his waiting to be interpreted as initiatory tests, which will allow the hero to achieve a palingenesis. 
His progress through the tropical forest, led by the beggar/initiating-master, has a symbolic function. The forest with its "nocturnal opacity; the glaucous opacity of undersea depths" is compared to "a mysteriously agitated sea [...] an ocean with its own currents and its secret tributaries, an ocean that nourishes its hidden life with the breath of flowers and the exhalations of the fermenting earth" (Radiance, 95). Was it not from such Silurian depths that life initially emerged? Even more so, the forest, just as the shadowy interior of the hut in which neophytes are usually confined during the enforced waiting period of the initiatory process, portrays those archetypal images offered by psychologists to "typify the eternal psychodrama of a violent death followed by a rebirth" (Eliade 1959: 90). Mircea Eliade (1959: 90) explains that the virgin forest, just like the savannah, symbolises both "hell and the cosmic Night, thus death and all possibilities." After having wallowed in the forest surrounded by decaying rotten vegetable matter and having symbolically returned to an embryonic state, in this clammy, tropical and dark place, "where everything is slit open like a ripe fruit bursting with warm and heavy juices, where everything is penetrated by everything else" (Radiance, 96), Clarence will be able to experience a rebirth and so attain a "higher level of existence" (Eliade, 1959: 128). As Roger Caillois (1950: 55) remarks, the impure can become an instrument of purification, for there is reversibility of the pure and the impure: "The impure can procure mystical force, or, what comes to be the same, can manifest it." Thus, the voyage of the Frenchman in Africa and his passage through the tropical forest have brought him redemption, peace and salvation.

\section{Conclusion}

Gide went to Congo with preconceived ideas about Africa and the Africans. He thought he would find humanity at the dawn of time and populations without civilisation. The convictions which he expresses in his books stem from a position of power and bear the sign of authority, that of the civilised coloniser. But the situation he witnesses transforms the aesthete and the dilettante that he was into a committed man, involved in a humanitarian struggle. The writings resulting from this mission, the Voyage au Congo and le Retour du Tchad and more particularly the accusatory article published in la Revue de Paris had positive consequences. They helped put an end to the injustices and the atrocities perpetrated towards the natives by the concessionary companies, charged with the collection of rubber. But at no time, does Gide challenge colonisation itself. He stresses the civilising action of France.

Camara Laye subverts the roles traditionally attributed to Europe and Africa. The African writer offers an ironical reversal of received ideas and invites us to reconsider established values. He combines his voice and his writings with those of Léon Laleau, Aimé Césaire and Léon Gontran Damas, who set themselves up against the detested 
"ci-vi-li-sa-tion" (Damas 1972: 41), in a material and soulless world. For Camara Laye, this "ci-vi-li-sa-tion" annihilates the black man, salt of the earth and the precious values sung by Aimé Césaire in his Notebook of a Return to my Native Land. Only these values are important.

Eia for those who have never invented anything

for those who have never explored anything

for those who have never subdued anything

those who open themselves up, enraptured, to the essence of all things,

ignorant of surfaces but enraptured by the movement of all things,

indifferent to subduing but playing the game of the world.

(Césaire 1995: 115)

For Camara Laye, Africa offers spirituality and appeasement to the white man. When at last, Clarence reaches the end of his voyage and of his quest, the king, laying his gaze on him, understands and accepts his feeling of abjection, his deprivation, and the existential vacuum within him. "Your deprivation itself, the gaze seemed to say. The frightful vacuum which is in you and which opens to me; your hunger which responds to my hunger; your abjection which did not exist without my permission, and the shame of it you feel" (Radiance, 252). Clarence realises that it is this life, "beyond death" which he has come to seek in Africa. In the final apotheosis, when the king slowly "closes his arms around him and his great mantle envelopes him", Clarence discovers Love in a mystical fusion with the cosmos (Radiance, 279).

\section{Notes}

1 The translation of Gide's texts is that of the author. "Les îles, ce matin, se disposent sur le grand miroir du Congo d'une manière si harmonieuse qu'il semble que l'on circule dans un parc d'eau" (Journal, 701).

2 "Ni le jasmin, ni le muguet, ni le lilas, ni la rose n'ont une odeur aussi forte et aussi exquise que les fleurs de cet arbuste" (Journal, 794).

3 "Pas une fleur; aucune note de couleur autre que la verte" (Journal, 701).

4 “Ce matin, le Logone rejoint assez exactement l'image que je m'en faisais" (Journal, 874).

5 "Le spectacle se rapproche de ce que je croyais qu'il serait; il devient ressemblant" (Journal, 702).

6 The forest of Brocéliande, situated in Brittany, is the place where many episodes of the epic legend of King Arthur and the Knights of the Round Table took place.

7 “... cette forêt me déçoit. J'espère trouver mieux ailleurs. Celle-ci n'est pas très haute; je m’attendais à plus d'ombre, de mystère et d'étrangeté. Ni fleurs, ni fougères arborescentes; et lorsque je les réclame, comme un numéro du programme que la représentation escamote, on me répond que 'ce n'est pas la région'" (Journal, 705).

8 "Les arbres laissent s'ouvrir des baies profondes de verdure, se creuser des alcôves mystérieuses, et si les lianes les enlacent, c'est avec des courbes si molles que leur étreinte semble voluptueuse et pour moins d'étouffement que d'amour" (Journal, 703).

9 "Ma représentation imaginaire de ce pays était si vive (je veux dire que je me l'imaginais si fortement) que je doute si, plus tard, cette fausse image ne luttera pas contre le souvenir" (Journal, 733).

10 "Qu'est-ce que vous allez chercher là-bas ? "-" J'attends d'être là-bas pour le savoir" (Journal, 683). 
11 "En Afrique, il allait chercher «le sauvage, le primitif: une humanité nue et sans histoire, une nature vierge de tout asservissement; le spectacle de la terre et de l'homme en deçà de la culture" (Gide in Durosay 1991: 21).

12 "Pour l'indigène, l'accidentel n'existe pas; la notion même du fortuit ne peut l'atteindre; le crocodile est 'naturellement inoffensif', et, s'il lui arrive de croquer un homme, c'est qu'un sorcier le lui a livré" (Journal, 835).

13 "Plus ou moins enfoui sous les sédiments patiemment apportés par la culture, se trouve le moi 'barbare' qu'il est fascinant de retrouver à l'état natif" (Gide 1988: 35).

14 "la sauvagerie africaine" (Gide 1988: 34).

15 "Je ne veux point faire le noir plus intelligent qu'il n'est. Mais sa bêtise, quand elle serait ne saurait être comme celle de l'animal, que naturelle" (Journal, 752).

16 “'Pourquoi n'a-t-on pas récolté le manioc en temps voulu ?' En général, le 'pourquoi' n'est pas compris des indigènes; et même, je doute si quelque mot équivalent existe dans la plupart de leurs idiomes. [...] Il semble que les cerveaux de ces gens soient incapables d'établir un rapport de cause à effet" (Journal, 752).

17 "Je ne les crois pourtant capables que d'un très petit développement, le cerveau gourd et stagnant le plus souvent dans une nuit épaisse" (Journal, 765).

18 “... il semble qu'ils s'affinent et se spiritualisent tandis qu'on remonte vers le Nord" (Journal, 836).

19 Fondouks are inns or warehouses in Arab countries.

20 "Il a poussé jusqu'au Tchad à seule fin apparente de chasser les papillons, étudier le Second Faust, éreinter Britannicus et comparer les phacochères à Henri Béraud" (Dambrus 1983: 23).

21 "Ce gigotement saugrenu des dames mûres est assez pénible" (Journal, 748).

22 "Extrêmement pénible, le trémoussement éhonté des matrones sur le retour" (Journal, 752).

23 "Beauté $[. .$.$] des enfants au torse nu, rieurs, au regard languide" (Journal, 685).$

24 "Tout ici semble promettre le bonheur, la volupté, l'oubli" (Journal, 685).

25 “Combien admirablement ces peaux noires se mêlent et s'harmonisent dans la grande symphonie végétale, - au point que les corps se distinguent à peine des troncs des arbres et semblent mythologiquement métamorphoser leurs membres en branches et en lianes" (Journal, 874).

26 "Ils sont venus dans le pays avec l'idée bien arrêtée d'y faire fortune, et rapidement. Au grand dam de l'indigène et du pays, ils y arrivent" (Journal, 719).

27 "Ce pauvre bétail ruisselait sous l'averse. Nombre d'entre elles allaitaient tout en travaillant" (Journal, 739).

28 "En acceptant la mission qui me fut confiée, je ne savais trop tout d'abord à quoi je m'engageais, quel pourrait être mon rôle, et ce en quoi je serais utile. À présent, je le sais, et je commence à croire que je ne serai pas venu en vain" (Journal, 744).

29 “...le pays sort de sa longue misère. Des cultures partout, des cases propres, des villages peuplés des gens bien nourris, bien portants, prolifiques, nus et heureux" (Cahiers André Gide 1981: 50).

30 "Il est grand temps de se ressaisir, de mettre fin à un régime qui n'est pas seulement stupide et déplorablement onéreux, mais inhumain et déshonorant pour la France" (Journal, 1040).

31 There has existed for the past 50 years some controversy as to the identity of the author of the Radiance of the King. There have been contentions that Camara Laye did not write his book. Such allegations cast discredit on many African works written in French. In 2002, Adèle King, the author of a previous work on Camara Laye, published a book entitled Rereading Camara Laye in which she concludes that Camara Laye might not have been the sole author of his first two novels. It is quite probable that, as is often the case, an editor from the publishing house, or someone else, has read and altered the book, but, considering questions of consistency, etc., with Camara Laye's later works, I believe he is the true author.

\section{Works cited}

Brazza, René Savorgnan de Brazza.1887. Conférences et Lettres de P Savorgnan de Brazza sur ses trois explorations dans l'Ouest Africain. De 1875 1889. Paris: Dreyfous.

Cahiers André Gide, 10. Correspondance André Gide Dorothy Bussy. II.1981. Paris: Gallimard.

Caillié, René. 1996. Voyage à Tombouctou. Paris: La découverte. 
Caillois, Roger. 1950. L'homme et le sacré. Paris: Gallimard. Idées.

Camara, Laye. 1954. Le Regard du Roi. Paris: Plon.

. 2001. The Radiance of the King. Trans. James Kirkup. New York: New York Review of Books.

Césaire, Aimé.1995. Notebook of a Return to my Native Land. Trans. Mireille Rosello with Annie Pritchard. Newcastle upon Tyne: Bloodaxe Contemporary French Poet 4.

Chadourne, Jacqueline. 1968. André Gide et l'Afrique. Le rôle de l'Afrique dans la vie et l'œuvre de l'écrivain. Paris: Nizet.

Damas, Léon Gontran.1972. Soldes in Pigments. Névralgies. Paris: Présence Africaine Poésie.

Dambrus, C. 1983. Les dossiers de presse du Voyage au Congo. Bulletin des Amis d'André Gide 58, avril, 239_ 49.

Durosay, Daniel. 1988. Images et imaginaire dans le Voyage au Congo: un film et deux auteurs. Bulletin des Amis d'André Gide 80, octobre, 9-30.

1991. Retouvé à Berlin: "Reise zum Kongo". Bulletin des Amis d'André Gide 89, Janvier, 7-26.

Éliade, Mircea. 1959. Initiation, rites, sociétés secrètes. Paris: Gallimard. Idées.

Gide, André. 1954. Voyage au Congo and Retour du Tchad. (Journal 1939-1949). Paris: Pléiade. 1988 [1928]. Conférence de Bruxelles. Bulletin des Amis d'André Gide 80, octobre, 31-36.

King, Adèle. 2002. Rereading Camara Laye. Lincoln, London: University of Nebraska Press. 